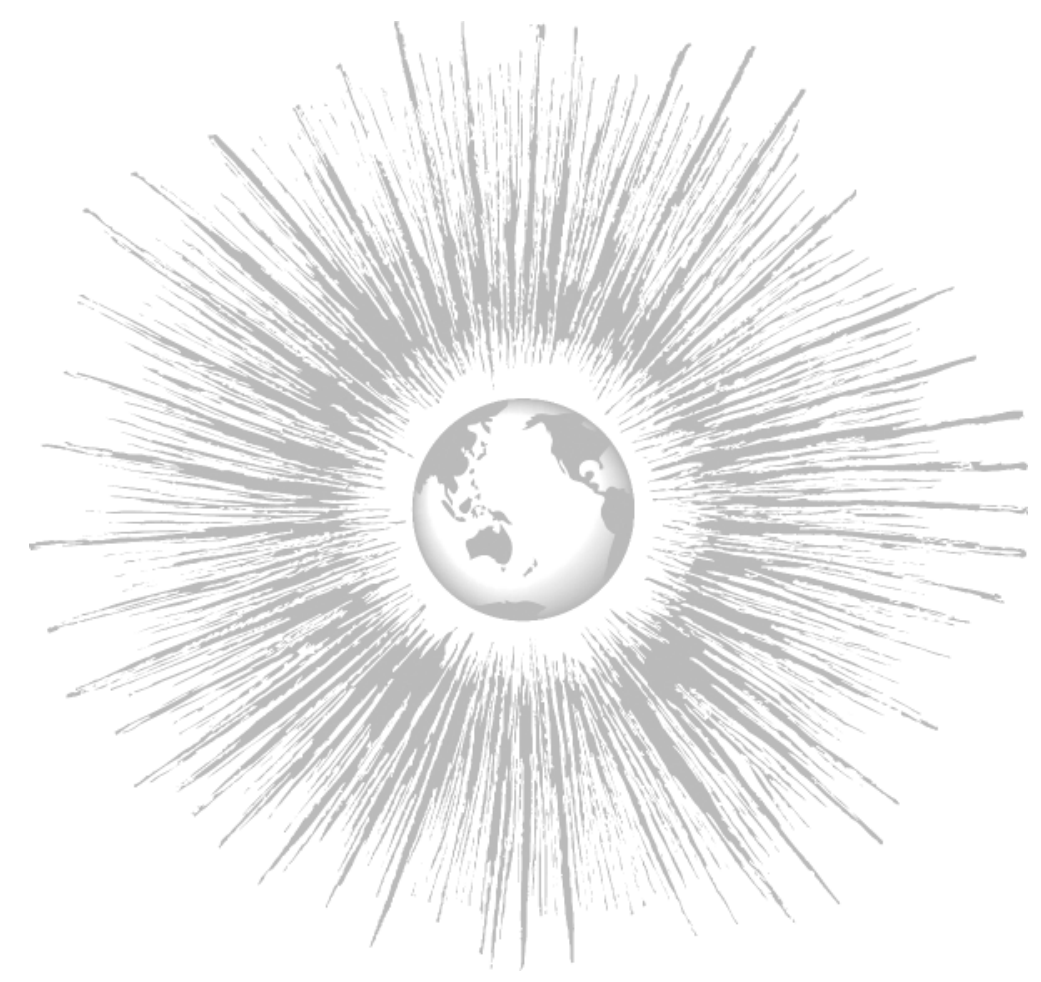

ABSTRACT:

The study of globalization, prominent in all fields of social science, scarcely draws upon the insights generated by the world-systems theory. In this essay, I delineate five key dimen sions on which a world-systems approach diverges from a world society approach. When linked together, these five stages offer support for a dependency perspective that was

\section{Globalization from a World-System Perspective: A New Phase in the Core-A New Destiny for Brazil and the Semiperiphery?*}

\section{Kathleen C. Schwartzman}

Global convergence seems unstoppable. Like an avalanche, new social, eco$\mathbf{J}_{\text {nomic, and political forms are spreading around the globe. The spread of }}$ organizational and institutional forms has been documented in such domains as mass education, suffrage and education for females, human rights, increased power of central banks, population control, and deregulation of labor markets. Brazil too has adopted new organizational and institutional forms. In an ongoing endeavor, many political scientists, sociologists, and economists are exploring the nature, rate, and consequences of this global transformation.

It is paradoxical that the world-system perspective seems to have lost its salience in the intellectual debate on globalization. More than a label is at stake here. Martinelli's contention that a "world society cannot be equated to a world system" (2005:244), captures the fissures that exist among various schools of globalization. The goal of this essay is to delineate numerous ways in which a world-system approach differs from a "world society" explanation. I believe that the world-system perspective offers better theoretical leverage for synthesizing the myriad strands of research and the extremely diverse research findings. It also provides a more persuasive explanation for the observed global convergence.

\section{Kathleen C. Schwartzman \\ Department of Sociology \\ University of Arizona \\ Social Science Bldg Rm 400, PO 210027 \\ Tucson, AZ 85721 \\ kcs@u.arizona.edu \\ http://fp.arizona.edu/soc/kathleen schwartzman.htm}

* The author would like to thank Ron Breiger, Michael Burawoy, Terence Halliday, William Robinson, Robert Ross, and anonymous reviewers for their suggestions. This research was supported in part by a grant form the University of Arizona Foundation and Office of the Vice President for Research.

JOURNAL OF WORLD-SYSTEMS RESEARCH, XII, 2, DECEMBER 2006, 265-307 http://www.jwsr.org

ISSN $1076-156 \mathrm{x}$

(C) 2006 Kathleen C. Schwartzman 
This leverage derives from the fact that it connects the global and local processes and, it theorizes those connections. The dialogue between the theory and the Brazilian case provides an illustration of the diffusion process as it moves along an embedded causal sequence from global "need" to local "adoption."

Global convergence has been approached from divergent perspectives that often render different conclusions. While a myriad of economic, political, and social convergences are of interest to globalization researchers, ${ }^{1}$ shifts in a nation's economic governance, particularly the shift from corporatist forms to more liberal ones, are of primary interest to one subset of scholars. ${ }^{2}$ My references here are primarily to those institutional shifts associated with the liberalization of capital accounts. In 1950, there were few financially open countries (the United States, Canada, and Germany), but by 1988, most OECD countries were totally open in current account payments and partially open in capital flows (Quinn and Inclan 1997: 805). Even though economists, political scientists, and sociologists have all studied these shifts, amazingly, many of the published bibliographies of these works lack overlapping references.

Because of the vast and fractured nature of the scholarship, it is a challenge to summarize the approaches in a succinct way. The continuum sketched by Goertz and Diehl (1992) highlights the differences found in the literature. The hypothesized diffusion mechanisms can be placed on a continuum between norms in the anthropological/sociological sense, on the one hand, and power on the other. ${ }^{3}$ Many scholars working within the world-culture or world-polity

1. The claim of convergence is challenged in a number of ways, ranging from highlighting the variations to negating the phenomenon. Fourcade-Gourinchas and Babb (2002) show how the standard set of neoliberal policies is differentially incorporated depending on the political regime, level of economic development, and cultural traditions regarding the role of the state in the respective countries. Fligstein (in looking at developed nations) concludes that there is "no evidence for convergence in...firms and markets across advanced capitalist societies (200I:I9I).

2. This general focus is narrowed further depending on the nature of the study. Simmons and Elkins (2004) and Quinn and Inclan (1997) examine the governance shifts in policies regulating the current accounts, capital accounts, and exchange rates. Haggard and Maxfield (I999) focus on liberalization of capital movements.

3. The continuum assumes that policy adoptions result from diffusion. The diffusion mechanisms are in contrast to policy adoptions arrived at independently. Like many authors, Goertz and Diehl (1992) advocate a middle ground. They analyze the convergence on the international practice of decolonialization from the perspective of norms, but controlling for self-interest. They also offer a typology of norms that blends dimensions of power, self-interest, and deontology with norms (hegemonic, cooperative, and decentralized norms, respectively). paradigm could be placed closer to the "norms" end of the continuum. Perhaps the leading and most widely employed sociological perspective, cataloging and accounting for global isomorphism, is the world-polity or world-cultural model (Strang and Meyer 1993; Meyer et al. 1997; Boli and Thomas 1999). First and foremost, this paradigm postulates that global isomorphism connotes diffusion. ${ }^{4}$ Institutions, actors, and nations are exposed to a set of norms, frames, theorizing, and prescriptive models of action. These models spread through associational and/or global cultural processes. The learning and embracing of models occur when actors jointly participate in international networks (such as professional organizations, INGOs, or shared educational experiences), or, absent from such direct links, they identify with and desire to emulate other adopters. It may also spread under conditions of exchange dependence, although, they argue, many things seem to flow where interaction and interdependence are not self-evidently high (Strang and Meyer 1993:490). This isomorphism is facilitated, because these models are "highly codified and publicized" (Meyer 1993:497), and "theorizing" provides categories and the "formulation of patterned relationships such as cause and effect" (1993:493). Also isomorphism may be encouraged because states that do embrace these accepted frames may gain legitimacy while those that do not risk losing legitimacy, both domestically and internationally. They predict that the diffusion-generating power of theoretical models varies with the extent to which they are institutionalized, that is, built into standard and authoritative interpretation and schemas (1993:495). Significant to this explanatory perspective, theorizing will produce patterns different from those that would flow from rational decision-making (1993:500). It is the "compelling logic" of the theoretical models that generates the "consensus."

While power seems alarmingly absent from this particular convergence scholarship, it is intentional. In reacting to the "realist" approaches of the international relations which might explain the diffusion in terms of a rational reaction to a balance of payments crisis (Haggard and Maxfield 1999), Meyer et al. advocated a reconsideration of global cultural processes (1997:147, 167). The

4. The claim of diffusion is challenged by Wilensky, who argues that the appearance of these phenomena is the result of timing, rate, and level of industrialization, and the subsequent character of national bargaining arrangements between major blocs of economic power. Wilensky writes "I have repeatedly found that the external pressures that are labeled 'globalization' have little or no effect in explaining social policies or system outputs.... What counts are national differences..." (2002:640). It is important to note that Wilensky focuses on advanced capitalist societies, not developing ones. 
spotlight on global culture was also a rejection of the micro (a rational actor), macrorealist (power hierarchy), and the microphenomenological (a rich mix of local and external odds and ends) approaches.

Power or coercion models define the other end of the continuum. Power is the hypothesized mechanism and the model's coercive quality follows from the exercise of that power over outcomes for those who are without power. Power, for example, is held by those who have capital for investment, and power is exercised through markets. Strange's work (1996) exemplifies the power end of the continuum. In explaining the retreat of the nation-state and the consequences for well-being, Strange looks at the shift in the global balance of power attendant with integrated world markets and constructs an argument of how the certain actors who hold power (it could be the TNCs) force the retreat of individual states. Others, like Pauly (1997) pose a mechanism which falls between the two. He asserts that individual states, by choosing (and that is the key word) to gain the advantages of international markets, and by opting for openness and integration, are constrained to, and therefore do accept new institutional forms. He identifies two sets of actors, IMF and bankers on the one hand and international institutions that help states address their legitimacy problems. ${ }^{5}$

Crudely put, and taking slight liberty with the Goertz-Diehl continuum, it helps to separate perspectives that advocate a mechanism that "appears" to be based on volition from those that "appear" to be based on coercion. In the first, "consensus" derives from the fact that individual nations voluntarily endorse an organizational form, and freely, without force or constraints, adopt it. Many authors concentrate on the endogenous mechanisms, be they an elite's recognition of the necessity of the reforms, institutional arrangements, types of states, degree of majoritarianism, independent central bank, or the factor endowments that facilitate reforms (Quinn and Inclan 1997). These models do introduce exogenous factors, in either the form of international networks to which domestic actors belong, or of international economic crises to which domestic actors respond. In contrast, the "coercion" derives from the fact that actors in semiperipheral and peripheral countries implement exogenously generated institutional reforms. Nations are seen as obligated to accept certain organizational forms, not just because they are constrained based on their own prior choices, but because the very construction of their choices and the attendant constraints Pauly. are determined exogenously. Because there are no occupying armies or visible signs of force installing these reforms, I will substitute the concept of "consent" for "corecion." Clearly, there are many theoretical perspectives located on this continuum, representing different explanatory pathways from the macro to the micro. The Goertz-Diehl continuum offers one way to arrange the fragmented literature.

In addition to different hypothesized mechanisms of diffusion, there is a substantial array in what is to be explained. Guillen, for example, is interested in explaining the respective paths to global integration taken by Argentina, Spain, and South Korea. ${ }^{7}$ Kogut and Walker examine the fate of national ownership patterns in the face of globalization (200I). In other cases, authors wish to explain the adoption of a single organizational form such as the acceptance of Ministries of Science and Technology by a large proportion of nation-states (Jang 2003). Or, authors want to account for the adoption of a bundle of reforms regarding the economic and monetary systems (Simmons and Elkins 2004).

One way to formalize the dissimilarity of orientation is to "situate" the research along an embedded causal sequence that unfolds from global shifts to local consequences. The sequence begins with the core nations experiencing a transformation in their own economic system that requires a corresponding transformation in noncore locations of the world-system. This transformation is accomplished through new paradigms, new emissaries, and new incentive structures. The third node is the noncore adoption of the new form. And, at the end of the sequence are the intended and unintended consequences. This causal sequence parallels the realist models that envision chains of organizational control from major powers into local arenas (an interpretation criticized by Meyer et al. [1997:I6I]). It differs from the realists' perspective by its reintroduction of world-systems concepts, such as phases of capitalism, and core-noncore dependency. In much of the non world-systems scholarship, change takes place "somewhere" (or is absent) in the international sphere. The cause and

6. This has to be consent in the Gramscian sense. Often nations may initiate and implement the organizational form without any apparent outside pressure. Thus, the challenge to the world-system perspective is to define how this consent is different from consensus. Following Gramsci, this consent is precarious because there are penalties behind it.

7. Guillen's (200I) study is reminiscent of the seminal work by Barrington Moore. The transformations that nations undertake in response to an economic impulse (commercialization or globalization) are contingent upon the preexisting social structures. For both Guillen and Moore, the outcome is the paths to development. 
"place of origin" are not the primary concern in the world-cultural perspective which often "enters" the explanatory sequence after the emergence of some new organizational form. From a world-system approach, a new model originates with a transformation of capital (the cause and the phase) in the core (the place) (Rodrik 2000; Block 1996).

Some scholarship is most attentive to the third position in my causal sequence, the specifics of local implementation. This scholarship includes both large-N cross-national and case studies. Some authors present a detailed quantification of the organizational outcome, e.g., the changes in ownership or regulation (Kogut and Walker 200I). Comparative studies show how country-specific historical continuity and organizational ecology generate a diversity of adopted organizational forms. This diversity might result from the evolving interaction between the global forces and the local culture (Guillen 200I; Schofer and Fourcade-Gourinchas 200I), or it might result from deliberate resistance or negotiated orders (Sinclair 2005). Some research is more focused on a fourth position, assessing the extent to which newly adopted organizational forms produce the intended outcomes. This includes research that examines the unintended or more remote effects of the organizational shifts (Pauly 1997). Despite the fact that many scholars weigh in on the "causes" of global isomorphism, their research agendas vary widely.

Different explanations are also byproducts of methodological differences. Two aspects of sample selection contribute to this. First, by pooling cases across several decades, many studies are less attentive to the historical phase. In contrast, a world-system frame acknowledges that global dynamics vary with phases of globalization. The trade phase has characteristics that differ from the foreign direct investment and the debt phases, all of which differ from the foreign capital portfolio investment phase. A multinational may invest in a country because of its natural resources (copper, oil, and etc.), because of its large domestic market, or because of its lower labor costs. Direct foreign investment flows are dictated by criteria which differ from those governing foreign portfolio investments. Receiving nations also have differential power to negotiate or resist depending on the phase. Phase identification is critical, because when authors generalize and refute the argument of homogeneity by demonstrating the heterogeneity of adopted organizational forms, the data sometimes are drawn from an earlier phase. Guillen, for example, refutes the notion that countries automatically accept a single organizational form by demonstrating the different developmental paths that countries took in responding to the impulse of globalization. He identifies nation-state variation in firm structures and economic profiles and, significantly, the variation in the nation-state's relationship to foreign capital. His reference, however, is to manufacturing, not portfolio flows. Quinn and Inclan find that their variable of partisanship and its interaction with economic structure are significant in explaining which OECD nations deregulate their international finances, but their model cannot account for differences in the I980s (1997:793, 80I). While their model may permit generalizations regarding foreign direct investment, the same set of factors loses leverage in the debt and subsequent portfolio phases. This is a warning about the importance of theorizing global phases. Likewise, Simmons criticizes Strange for not having a nuanced conception of power (1998:137), but one way to introduce "nuance" into the concept of power is to derive it from its appropriate global phase. Generalizations about diffusion drawn from the phase of direct foreign investment might well misspecify the dynamics of foreign portfolio investment. The new phase of globalization is unique in that capital is mobile on two scores, it's private foreign capital and it's in portfolios. ${ }^{8}$ The world-system paradigm requires a theorizing of phases in a way that other theoretical perspectives do not.

Second, by pooling cases from many countries, studies end up being inattentive to "place" in the world-system hierarchy. Generalizations derived from both case studies and large quantitative data sets do not always distinguish conceptually between developed and developing countries. Case and comparative studies frequently focus on core nations, while quantitative analyses bundle together nations including peripheral and semiperipheral ones. ${ }^{9}$ Some comparative studies have a mix. Agents in the core understand the importance of worldsystem placement. On the occasion of the formation of IRG (the International Ratings Group, a global network joining four regional rating agencies), the chairman of one of the founding groups, Global Credit Rating Company, said "emerging markets are fundamentally different to the developed markets in the US and Western Europe" (JCR-VIS 2006). One general criticism of theories that fall on the "coercive" end of the continuum is that they ignore the documented variation in outcomes. It is important to recognize the role that sample choice (both in time and space) has in bringing about this variation. While critics argue that not all diffusions are equal, I would amend this to note that not all samples of nations and time periods are equal. Generalizations about global isomorphism derived from a study of core nations might well misspecify the

8. Martinelli believes that scholars miss much of the novelty of the new global order because they focus on the economic and financial sphere. But even in the financial sphere, this is a fundamentally new phase.

9. Fligstein's evidence comes from advanced capitalist societies (200I:19I). Quinn and Inclan (I997) study 2I OECD nations. 
dynamics of developing nations. While many quantitative studies do control for GNP, world-systems analysis requires theorizing global "location" in a way that other perspectives do not.

What is the most suitable methodology for examining global isomorphism? In their 1992 article, Goertz and Diehl observed that little was written on the methodology of studying norms but there was some agreement on the casestudy as the principal mode of research. The recent sociological work continues the comparative case tradition, but more commonly utilizes large quantitative data sets. Research with many countries is really the only way to detect the scope and rates of global convergence over time. On the other hand, small-N comparative studies offer an opportunity to fill the gap between theorizing and quantitative findings, and to discover the mechanisms of individual country adoption. ${ }^{10}$ Clearly a case study cannot adjudicate among the multitude of explanations. In much of this literature, adjudication comes from inferences derived from statistical analysis or from inferences made from multiple cases specifically chosen for their comparative suitability. Each has its respective advantages and handicaps. Case studies are vulnerable to the same sociologists' uncertainty principle that is leveled against ethnography - the closer you get to measurement on one dimension, the further you recede from others (Burawoy I991:2). Within the globalization literature, Sinclair consciously works through this problem by "refuting" alternative models through the use of the counterfactual (2005). Understanding globalization has to be a collective effort.

How does isomorphism occur, or how does the "theorizing" get diffused? The Brazilian case provides insights regarding the mechanisms of isomorphism. I use the Brazilian case as a way of "trying on" different explanations. Abstracting key concepts from the world-polity/world-culture and from the world-system paradigms, I construct two "ideal types" ("consensus" and "consent," respectively) (Table I). By tracking the case of Brazil through the embedded causal sequence described above, it is easier to understand why some scholars might describe the diffusion processes as coercive. The term "consent" allows us to accept conclusions drawn from other research situated along the embedded causal sequence, and to see that while Brazil freely adopted the recommended reforms, they had little choice.

10. Excellent comparative case work is found in Fourcade-Gourinchas and Babb (2002) who focus on the paths toward the market paradigm taken by four countries, Guillen (200I), who uses the comparative case approach to see differences, and Haggard and Maxfield (1999) who study Indonesia, Chile, Mexico, and South Korea.
Table 1 - Two Ideal Types

\begin{tabular}{|c|c|c|}
\hline & Consensus (Diffusion) Model & Coercion (Coercion) Model \\
\hline $\begin{array}{l}\text { Social origins of new } \\
\text { models }\end{array}$ & $\begin{array}{l}\text { New idea (typically) in developed } \\
\text { nation }\end{array}$ & $\begin{array}{l}\text { New phase of globalization: ties } \\
\text { core to semiperiphery/periphery in } \\
\text { new way }\end{array}$ \\
\hline Frame offered by agents & $\begin{array}{l}\text { Superior theory, virtues in terms of } \\
\text { standard notions of efficiency, justice } \\
\text { or progress }\end{array}$ & $\begin{array}{l}\text { To reduce the transactional } \\
\text { uncertainty of international } \\
\text { markets }\end{array}$ \\
\hline Agents/promoters & $\begin{array}{l}\text { Neutral: Disinterested (public) } \\
\text { experts, technicians who are } \\
\text { economists, theorists, with an } \\
\text { abstract concern for better, more } \\
\text { efficient models. Institutionalized, } \\
\text { could be INGOs }\end{array}$ & $\begin{array}{l}\text { Vested interests: (Private) } \\
\text { technicians are closely linked to } \\
\text { actors with a vested interest in } \\
\text { capital flows. }\end{array}$ \\
\hline $\begin{array}{l}\text { Frame offered to } \\
\text { potential adopters, the } \\
\text { compelling logic }\end{array}$ & $\begin{array}{l}\text { Universal. Benefits include increased } \\
\text { productivity or gains in national } \\
\text { legitimacy. }\end{array}$ & $\begin{array}{l}\text { Country-specific. Exhort } \\
\text { "emerging markets" with scores } \\
\text { to conform under threat of loss } \\
\text { of capital flows. }\end{array}$ \\
\hline $\begin{array}{l}\text { Degree and nature of } \\
\text { link between } \\
\text { disseminators and } \\
\text { adopters }\end{array}$ & $\begin{array}{l}\text { Agents and adopters weakly related, } \\
\text { decoupled. Identify with others who } \\
\text { are ultimately similar: adopters have } \\
\text { a consensus regarding the models. } \\
\text { Theorization may substitute for direct } \\
\text { contact. }\end{array}$ & $\begin{array}{l}\text { Agents and adopters tightly } \\
\text { linked. Promoters speak directly } \\
\text { to prospective adopters. }\end{array}$ \\
\hline Penalty for ignoring & $\begin{array}{l}\text { Non-compliance may have } \\
\text { observable outcomes of a } \\
\text { nonmaterialist nature. Loss of } \\
\text { legitimacy }\end{array}$ & $\begin{array}{l}\text { Non-compliance has observable } \\
\text { outcomes of a materialist nature } \\
\text { outlined by agents. Loss of } \\
\text { capital }\end{array}$ \\
\hline
\end{tabular}

In Table I, I contrast the two ideal types on five key dimensions. First, it is important to specify the social origins of the new templates; second, to identify the theoreticians / agents / promoters of the templates; third, to describe how they are framed among disseminators themselves; fourth, to identify the rational offered to potential adopters; and fifth, to specify the link between promoters and adopters, including the likely penalty. Each of these is discussed below and illustrated with data gleaned from magazines, journals, newspapers, and business reports on the Brazilian and other Latin American "emerging markets." I have not included a discussion of a sixth dimension, the consequences of adoption. 


\section{BRAZIL'S CONVERGENCE - CAPITAL AND RULES}

In 2000, Investor Relations Magazine welcomed the progress. "LatinAmerican equity markets have entered a new era of liquidity and transparency, a time of building shareholder value" (PR Newswire 2000). Two milestones are trumpeted here; first that foreign capital has increasingly entered Latin American capital markets, and second, new rules regarding portfolio investment. In the vast literature on "globalization," one of the more exact usages of the term has come to stand for a worldwide adoption of a homogeneous set of rules for international and domestic economic engagement. These rules, derived from the theory of neoclassical economics and its application in the United States, generally include privatization, reduced intervention of the states in their own domestic economic affairs, and the free movement of goods, services, and capital across national boundaries. This ongoing isomorphism can be seen in a cluster of legal and institutional changes that affect how firms (or governments) issuing stocks and bonds have amended their governance structures. It can also be seen in legal and institutional liberalizations that affect capital flows. Globally, such capital controls have exhibited a downward trend that accelerated from the late I980s to early I990s (Miniane 2004:284). New laws, new monitoring mechanisms, shifting accounting practices, and the like, all facilitate foreign portfolio investments into and out of developing countries.

Brazil has received an increase in foreign capital, but it would not have materialized without prior shifts in the laws and institutions regulating those flows. Brazil's private corporations have embraced many of the new management and accounting schemes. The trend is for Brazilian entities to shed in varying degrees their local identities and assume corporate personalities with an American hue. In 200I, the Banco Rural, for example, followed the advice to replace its regional audit firm with a large renowned international audit company (Business Wire 2002a). A survey of 55 Brazilian companies showed that between 1998 and 2000 they had increased the number of pages of their annual reports from an average of 8 to 14 . In 1998 and 1999 , none of the annual reports spoke of the corporative governance structure. By $2000,12.7 \%$ of the companies included this discussion in their annual report. The general trend is to provide more information regarding spending and revenues to the potential investor and to do so using the templates offered by American accounting standards (Azevedo 200I). The hurdles to better governance come from the prevalence of family owned companies and the low percentage of shareholders without voting rights. One response to the demand for higher standards on governance in Brazilian companies (and to the inability to enact meaningful reform legislation) was the 2000 opening of a "New Market" within the Bovespa. To list on the New Market (Novo Mercado), companies were required to voluntarily adopt governance rules that were tighter than those required by legislation (Vilela 2005). In particular it offered protection to shareholders. Coffee also believes that the opening of Novo Mercado was a response to capital flight as Brazilian firms moved to list on the U.S. stock exchanges. Brazil even invited U.S. institutional investors to participate in designing the listing rules to guarantee that it would be investor friendly (2002, 1806).

These transformations and cultural shifts were not limited to private firms and banks. As governments (national, state, and municipal) and para-statal companies became more involved with the foreign capital markets through increased bond issuance, they have embraced international norms and frames associated with presentation and composition of annual budgets. A few examples illustrate these actions. Because the market [sic] was suspicious about the true value of the company, the finance director of the Brazilian-owned oil company (PETROBRAS) decided to change its accounting procedures to promote greater "transparency" for those financial markets (Global News Wire 1999). In 2000, the Central Bank ordered banks to provide interest rate information on a monthly basis, which then would be published on the Central Bank website (Global News Wire 200I). Numerous Latin American governments were undertaking the same actions. As Picciotto and Haines describe it "There have been emulation and transplantation of regulatory models, as well as movement to establish common approaches and standards, and to ensure cooperation" (I999:36I).

Brazil likewise is liberalizing its controls on capital. Miniane (2004) includes Brazil in a project, extrapolating the new 1996 IMF reporting procedures back to 1983 . He finds no change from 1983 to 1996 and greater capital account openness after 1997 (2004:285). But, Miniane notes, these measures are not always sensitive to country-specific liberalization episodes, and even though the index for Brazil remained at I (not liberalized) up until 1997, it started to liberalize in 1992. It was not however, an uninterrupted process. In 1995, for example, restrictions were placed on foreign capital inflows. Gustavo Franco, Director of the Central Bank in 1995 disclosed two concerns leading to these restrictions. First that the flood of foreign capital was entering to take advantage of the high interest rates while avoiding the 7 percent tax payable on some investments, and second, that Brazil was interested in capital that would stay in the country for longer periods (Wheatley 1995). The scores after 1997 capture liberalizations such as a corporate law signed by President Cardoso in November 200I. He committed Brazil to developing its capital markets, increased transparency, and protection for minority (foreign) investors. In summary, Brazil is rewriting its 
governance structures and undertaking capital accounts reforms that follow an international template.

Nevertheless, no amount of empirical data confirming (I) an improvement in governance and capital accounts and (2) a subsequent rise of foreign capital can adjudicate among the explanatory models. The embrace of international regulatory models by private and public entities could result from a Brazilian consensus regarding a well articulated "theorized" model with clear benefits or, it could result from something else. For purposes of this discussion, I treat "consensus" as the default explanation, and attempt to persuade readers (with the use of counterfactuals) that what actually happened could be better explained by the combination of the five dimensions of the "consent" ideal type. I proceed from the global level, and move forward along the embedded causal sequence to the final process of structural isomorphism. The Brazilian example helps to clarify the five dimensions on which the consensus perspective differs from the consent perspective, and it illustrates that although Brazil voluntarily consented to reforms, the explanatory sequence-when taken as a whole-shows why some theorists emphasize the role of coercion in explaining global isomorphism.

\section{THE SOCIAL ORIGINS OF A NEW MODEL: THE NEW GLOBALIZATION}

\section{New Ideas}

Where do new templates and theories come from? Since this is not the primary question of much of the diffusion literature, the factors that lead to new templates and select out certain actors over others are sometimes left unspecified. Jang, for example, in his analysis of the diffusion of Ministries of Science and Technology, writes "As the rationales of science and its impact on national development have emerged and spread globally..." (2003:120). He suggests that in the early phases of adoption, such ministries might be a response to the functional needs of certain nations and he shares the opinion of others who write that these rules and practices are likely to be linked in the core to prevailing theories of modernization (Strang and Meyer 1993:502). Because the research is focused on the observed isomorphism, the earlier instances are just posited as the starting point. It does appear that developed nations are centers of innovation, or at least that a majority of studies draw from cases where dissemination is of forms which have proven successful in the core. In sampling terms, we might describe the diffusion research as drawing from the population of coreinitiated innovations that are successfully diffused to many nations.

One might be content to rest the case there, asserting a vague (and nonproblematic "core-centric") account for the rise of a new template; however it precludes detecting even a potential for "coercion." In contrast, the worldsystem paradigm theorizes the origin of and need for new templates. As Arrighi argues, templates reflect their historical periods. The post-wwin period was dominated by "development economics" which articulated a specific doctrine based on postulates such as: "wealth could be attained by all," and the "basis of wealth was industrialization." That template also alleged the irrelevance of historical geography (pre-colonial legacies didn't much matter). Arrighi suggests that the counter-revolution, begun in the 1970 in response to the failures of developmental economics, was completed by 1985 . The new reigning idea-the neoliberal Washington Consensus-had no need for a theory of development. In the new vision, national poverty was now the result of bad government and the failure to follow certain policies (Arrighi ND:6). While the consensus model can simply acknowledge the new template as a starting point, the consent model must show that the content of the new template was related to the historical development, and that there was some core-driven urgency for its diffusion.

\section{The New Phase - Converting Dependent Nations into Emerging Markets}

The current widespread use of the word globalization trivializes it and misses the new configuration. The new globalization differs from earlier phases because it includes a flow of international capital that is now directed toward portfolio investment (FPEI). Portfolio equity refers to financial investments in companies. It can easily be altered or withdrawn with a click of a computer key. A growing proportion of investment in Latin America and Asia is portfolio equity'. From 1990 to 1994 the capital flowing to developing countries was five times that of the previous five years, "when there was a debt crisis and many of these countries had little or no access to international capital markets" (Calvo et al. 1996:123).

For developing or semiperipheral nations, this phase of globalization differs from the preceding ones. Previous global streams involved trade and foreign direct investment, and to some extent echoed the first global integration that went under the label of colonialism. In the earlier phases of foreign investment (FDI), full-assembly factories were located in countries for the purpose of capturing local markets. In the I950s and I96os the link between foreign capital flows and investment was tighter because flows were directed to particular investments, official projects, and particular users. This was "development economics." As direct-investment lending from commercial banks declined in the I970s, it rose from supranational public organizations, such as the IMF. This public funding ameliorated the feast-and-famine aspects of commercial lending that was prevalent during the I970s and early I980s (Bird 1996:486). 
In the current post "development-economics" phase, capital is directed from the developed to the developing world in a different way. The current worldsystem is characterized by an integration of world capital markets. And, in this new phase, "developing nations" have been redefined as "emerging markets." Whereas direct foreign investment and international loans went to "developing nations," now foreign equity flows go to "emerging markets." This point was highlighted by King and Sinclair as one of the important changes in the new global finance system (2003:345). And, Carneiro argues, in the 1990s, long-term foreign capital (which includes investment in the stock market) began to show gains over FDI and short-term capital (1998:95). Referring just to the U.s. current-account transactions, the BEA writes that "receipts and payments of income have grown fastest in recent years, mainly as a result of the rapid expansion of cross-border holdings of financial assets" (2002). The BEA attributes the 1990s' rise in financial-account transactions to "easing of governmental restrictions on financial institutions and markets, rapid innovation in financial techniques and instruments, and economic growth" (U.S. BEA 2002).

Brazil partook of this new phase. Trade, direct investment, and loans were not displaced, but they were joined by FPEI. Foreign direct investment to Brazil continues to flow but has shifted away from manufacturing (falling from $71 \%$ in late 1980 s to $55 \%$ in the mid 1990s) toward service (Carneiro 1998:99). Carneiro attributes this shift to an increase in franchising and to the opening of contracting, building, technical consulting and computer-related businesses, and insurance. Bank-intermediated loans have also reduced their importance (1998:84). In 1989, long term foreign capital (Carneiro's category which includes stocks and bonds but not debt) was . $5 \%$ of the GDP. In 1994 it reached $9.4 \%$. As is its nature, it was volatile and had dropped to $3 \%$ by 1996 , the last year in his study. Capital flowed to a growing number of Brazilian firms listed on the Sao Paulo stock exchange (Bovespa). In Sao Paulo, visits from foreign investors became so common that company developed English-language information sessions, and Bovespa saw more foreigners in 1993 than in any other time in its Ioo-yr history (McLeod 1993). Foreign trading as a percent of total value at Bovespa was around $15 \%$ in 1993 and rose to $27 \%$ in 2001 and to $31.9 \%$ in 2005 . All the indicators reflect the volatility of the capital flows, but also reflect a new phase.

\section{Why a New Phase?}

What motivated capital to seek out "emerging markets?" Several transformations, occurring in core nations converted semi-peripheral, peripheral or "developing nations" into "emerging markets." As the United States moved toward a service economy, it yielded rates of return lower than those previously found in production. To counter the move of production offshore, investment capital followed. Investment moved to where the supply of capital was low and the investor's returns were high. ${ }^{11}$ In 1993 Laderman observed that most investors did not spend their summer traveling abroad, but they made a lot of money if their dollars took the trip. The heavy flow of portfolio capital to emerging markets also was driven by a sustained decline in world interest rates." By late 1992 they were at their lowest level since the early I960s... attract[ing] investors to the high-investment yields and the improving economic prospects of economies in Asia and Latin America" (Calvo et al. 1996:126).

Second, the demographic shift in the U.S. population and the imminent retirement of baby boomers - an aging population that lives more off of savings and investments, meant that the so-called "emerging markets" became crucial to American investors. "For capital-rich developed countries, such investments appear a desirable way of diversifying risk and investing in productive assets that will, in a few decades, fund the retirement of the baby-boom generation" (Calvo et al. 1996:127).

Third, a crucial transformation had taken place in the nature of investors (Canterbery 2000). This period saw the rise of institutional investors, a phenomenon which increased both the volume and impact of investment. Drucker described it as an "unseen revolution" beginning in 1950 when GM financed and then placed its company pensions in the hands of professional asset managers who were responsible to the company. What was novel was that they were not fixed interest bearing, and they looked for returns outside of GM itself. By 1975, 50,000 such funds were in place and, in 1974, these pension funds held about $30 \%$ of the stock of U.S. publicly owned companies. Taken together, institutional investors - that is primarily but not only pension funds-controlled close to $40 \%$ of the common stock of the country's large, and many mid-sized businesses (Drucker 1996:106). These institutions have become corporate America's largest lenders as well as its largest owners. Drucker called it "Pension Socialism." Useem, who disputes the "socialism" claim but not the consequence, writes: "Peter Drucker's early forecast of pension fund socialism has not come to pass in American, but something akin to mutual-fund capitalism has achieved much the same level of concentrated firepower" (1996:259). This firepower, he argues, derives from the fact that institutional holdings rose from $16 \%$ in 1965 to $46 \%$ in 1990. And, U.s. investors have overcome their global shyness. "Dreyfus, for

11. Ecuador, after opening up its stock markets, was (according to a Reuters survey) among Latin America's most profitable stock markets rewarding investors with a 22 per cent return (in US Dollars) in 1994 (Colitt 1995). 
example, formed its International Equity Fund in June 1993... [and] Paul Nix, manager of the Dreyfus fund, placed two-thirds of his newfound assets in foreign stocks. If you're a U.s. Investor concerned with limiting volatility and seeking higher long-term returns...there are good reasons for adding a foreign component to your portfolio" (Useem 1996:263). These factors transformed the investment world, both in content and in location and they "bred the greatest bull market in securities in American history" (Canterbery 2000:3). There was also a certain 'band wagon' effect. Large flows of capital to one or two countries made other investors more willing to invest. Despite its modest appearance, ${ }^{12}$ it is reasonable to describe this as the beginning of a new phase.

Many analysts conclude that such changes in the organization of savings and investment along with new competitive pressures in core nations brought about the internationalization of financial markets (Picciotto and Haines 1999:355). This internationalization was also a way, Fourcade-Gourinchas and Babb argue, to compensate for the collapse of the strong international monetary system that had functioned in the post wwII period (2002:537). There is disagreement over whether to call this new global capitalism an integration of multiple markets or a single market. Feldstein advocates the former: "Although most of the legal barriers to international capital mobility are now gone, the world capital market remains essentially segmented along national lines" (1995). He offers as evidence the fact that most saving stays in the country in which it originates. Picciotto and Haines also judge globalized finance not to be a single global financial market, but local markets rooted in different socioeconomic structures with their own patterns of savings, investment, and regulatory traditions that have become linked internationally by a relatively small number of global firms that have the organization and technical capacity to trade on a global basis (1999:355). Others see a shift toward a single market. Useem argues that American investors avoided international investments only until the I99os (American investors kept $94 \%$ of their financial assets at home and Japanese were even more domestic, placing 98\% in Japanese securities) (1996:263). Block also judges the global financial integration to be close to a world economy (1996:200). In a similar vein, Dicken writes that before 1960 there was really no such thing as a world financial market (1992:364). While these authors differ slightly on the date of global integration, most judge the I990s as the early stage of a single financial market.

12. Feldstein writes that only I0\% of the assets in the 500 largest institutional portfolios were invested in foreign securities (1995).
The analysis of the origins of the new organizational form can buttress the claim of a world-system explanation on several grounds. In contrast to research agendas that treat all nations as equal, it specifies where and why new forms originated in the core countries. It also provides a reason for why the new forms take the shape that they do-they are in response to a problem located in the core. In contrast to research agendas that focus on the spread of organizational forms independent of the content, this perspective identifies the nature and imperative for global isomorphism, and therefore contributes to an understanding of why some might label the mechanism of diffusion as being coercive. The need for global capital mobility requires the demolition of segmented capital markets and the convergence of many markets into one.

\section{THE FRAMEः THE SOCIAL CONSTRUCTION OF EMERGING MARKETS}

\section{Prerequisites for Capital Mobility: Liberalism and Transparency}

This new phase, unfolding in the core, could not have been realized without accompanying transformations in developing nations. As Ross and Trachte write, the new Leviathan of global capitalism confronts local and national actors with their respective country-specific organizational routines (1990:16). Emerging markets needed to improve their hospitality toward foreign capital. Investment corridors have requirements not necessarily identical to trade and direct foreign investment corridors. As the global economy shifted toward service industries, the freedom of trade came to include banking, brokerage, and insurance services, along with the argument that they should be treated no differently than steel (Block 1996:199). Formal barriers to trade and capital flows have been reduced since 1997, but Rodrik argues, the international markets are not as "thick" as they could be (2000:179). Newer transformations were of crucial importance in rendering recipient countries worthy of investment flows from the developed nations. The emerging markets required two crucial reforms: (I) unlimited access to investment opportunities, and (2) detailed information regarding those opportunities. While privatization, deregulation, and liberalization facilitate the entry (and guarantee the exit) of outside investors, transparency gives investors information about the potential security/risk of their investments. ${ }^{13}$ Pressure was building in the investment community to

13. This theme is reflected in work of others who look at the global convergence of laws. Halliday and Carruthers, paraphrase one of the UNCITRAL delegates as saying "countries will not attract capital if they cannot offer investors sets of laws that provide investors confidence they can get their investments out in a fair and orderly way if investments go bad" (2003:2). Their focus is on the legal construction of markets in 
liberalize third-world markets and allow more foreign investment. Once investors have access to emerging markets, what matters most is knowledge about risk. Liberalism without transparency is treacherous.

Insistence regarding liberalization took, and continues to take, the form of encouraging nations to put everything on the auction bloc. Foreign shareholders required capital market openness, market regulation, and investor protection. In 1994, for example, Ecuador's financial sector was the fastest growing non-petroleum part of the economy. Although it was just beginning to revamp and open its capital markets, and the Securities Markets Law offered greater efficiency and transparency, the financial consultants advised that to maintain the same growth, the government had to offer investors more options (Colitt 1995). This was a complaint against a stalled privatization program and a request for the sale of more public enterprises. Likewise, the Brazilian government has been repeatedly encouraged to relinquish its national holdings. Commenting on the high Brazilian deficit, a PR Newswire editor suggested that "If the government cannot reduce the deficit, accelerated privatization might help Brazil to regain a measure of financial stability...spinning off assets like Banco do Brasil, a national bank, and Petrobras, the national oil company, would show investors the country remains serious about state reform" (I999d). The main source of the spectacular growth in net foreign investment in Brazil is portfolio investment and direct investment due in large part to the privatization programs (Garcia and Valpassos 2000:15I).

Pressure regarding the second took, and continues to take, the form of encouraging firms and governments to adopt transparency. For the custodians of the Latin-American capital market (Bank of New York and State Street, Bank of Boston, Citibank, and Santander, to name a few), the domestic markets, with their often idiosyncratic operating rules, are extremely risky. Obviously foreign shareholders will not profit from capitalizing companies whose business practices are questionable. Investors have a right to transparency. They want to know that their investments are being used responsibly and that there is a nonporous relationship between investment, productivity, and profits. There was a clear need to eliminate corruption within the emerging markets; the move to a single market required transparency. In 1992, for example, the vice-Chairman of J.P. Morgan welcomed China's selection of nine mainland-based corporations

international agencies and the process of globalization of laws. Rodrik considers discontinuous political and legal jurisdictions as transaction costs, in the same way that transport costs or border taxes are transaction costs. These jurisdictional boundaries, he argues, pose serious constraints on international integration (2000:179). to seek direct listings on the Hong Kong stock exchange. He said "What I am particularly pleased about it is that it includes the tacit agreement to step up transparency, accounting rules, Western methods of auditing" (Ward 1992). The Chinese were being commended for heeding the advice given to them in 1983 by a Wall Street delegation visiting China.

The dual prerequisites of capital mobility (liberalism and transparency) have been intensified by the use of the Internet. By 1994, nearly 40 percent of Ecuadorian stock market volume was traded electronically (Colitt 1995). "In an age of significantly increasing international investments and financial reporting on the Internet, the need for a common worldwide financial vocabulary and framework for reporting is quickly making diverse national standards obsolete" (PR Newswire 200I). The Internet is a fundamental investment tool- $80 \%$ of investors reported that they accessed corporate information on the web, up from only $22 \%$ in 1996 (PR Newswire 1999d). Companies must be open and transparent to take advantage of the increasing number of on-line global investors. Therefore, a global financial system built on top of national economies with weak financial systems and poor monitoring mechanisms would remain extremely risky for investors.

A diffuse and yet unorganized preoccupation with the conditions of investment flows to emerging markets was growing in core nations. These preoccupations needed to be conceptualized and defined, and this happened through linguistic and organizational innovations. The shift to a single global market described in this paper can be thought of as an extension of processes identified by Carruthers and Espeland for an earlier period. ${ }^{14}$ The utilitarian (the new phase) and rhetorical (the theorizing) functions are connected in core nations.

\section{Creating a Vocabulary for a Single World-Capital Market}

The new global capital flows required a realignment of practices and cognitive frames. To facilitate this, a new vocabulary gained prominence. Take, for example, the word "transparency." There was a time when the word "transpar-

14. Carruthers and Espeland, in their analysis of the rise of double-entry bookkeeping, examine two crucial aspects of the new accounting practices. First, they reiterate, from the early sociological literature, that the emergence and development of a rigorous accounting are closely linked to the emergence of capitalism (I991:32). Second, they stress that above and beyond the utilitarian function, accounting offers an important rhetorical aspect. As trade ventures grew from individual traders, to multiple investors, to joint stock companies, a formal accounting acquired a new utilitarian and rhetorical importance (I99I:44-46). 
Table 2 - References to the term "Transparency"

$\begin{array}{cc}\text { Year } & \text { Frequency } \\ 1985 & 24 \\ 1990 & 106 \\ 1995 & 395 \\ 2000 & 2,283\end{array}$

Note: The frequencies in Table 2 are based on a count of the word "transparency" when used in reference to budgets or accounting practices of governments or companies. They were taken from the Business news sections of online LEXIS-NEXIS. These estimations are only suggestive because they are based on the population of journals and news services included in the LEXIS-NEXIS data base.

ency" primarily described overheads or the non-opaque quality of mirrors and glass. While accountants had regularly referred to the transparency of prices, the word acquired a much wider usage after 1990. It became common to use it in reference to the national budgets of developing countries. A new rhetoric supplanted an earlier one: just as "developing countries" became "emerging markets," words like "centralization", "planning," and "autarky" were replaced with "deregulation", "liberalization," and "transparency."

One organization was a trend setter in creating and operationalizing the concept that has since promoted and policed the changes necessary for converging financial markets. Transparency International (TI) was founded by Peter Eigen in 1993. During his tenure as a senior official of the World Bank who had worked in Latin America and Africa, he became dismayed with the corruption. TI works to persuade investing companies to stop paying kickbacks and bribes, and officials in receiving countries to stop receiving them (Economist 1993). Following the establishment of Tr's Corruption Perception Index (CPI), the term 'transparency' took on a life of its own and became sensationally popular. Table 2 documents the increasing use of the term "transparency." ${ }^{15}$

The global corridor for portfolio capital flows was paved with the new vocabulary and new monitoring procedures. GAAP200I, a report released by the world's seven largest accountancy firms, advocated a single worldwide financial-accounting and reporting framework based on high-quality International

15. Annual data for the period 1985 to $200 \mathrm{I}$ are displayed in graph form in Schwartzman (2004).
Accounting Standards (IAS). Their stated objective was to improve transparency and comparability of financial information (IFA 200I). The International Accounting Standards reports that "Approximately one-third of the 62 countries surveyed are responding to the challenge of convergence with an active agenda and proposed changes to national requirements" (PR Newswire 200I).

The analysis of the initial framing, new routines, and new vocabularies can buttress the claim of a world-system coercion-based explanation on several grounds. This conceptualization and corresponding vocabulary were the result of a need generated in the new phase. And, the framing was relational (from core to semiperiphery and periphery). It wasn't simply that transparency was superior or preferred, but that it is directed toward emerging markets.

\section{THE AGENTS: THE MODERN EMISSARIES OF GLOBALIZATION}

Anything that flows in a world-system composed of nation-states, be it commodities, capital, or theories, requires institutional settings and organizational routines on both sides of the exchange. During the early phase of the Portuguese empire, the Casa da India (in the core) joined with the Brazilian and Asian colonial counterparts (in the periphery) to orchestrate the extraction of colonial resources. Through the Casa da India, the Portuguese crown controlled trade with Brazil. The Casa included archives, accounting and price departments, and agents-colonial officers who enforced the general regulations. Over the subsequent stages of global development, the institutional pair and the organizational routines that managed core-semiperiphery flows were "modernized." In the mid I970s, when loans and debt repayment constituted part of the global flows, the core and semiperiphery/periphery were represented respectively by the IMF and the governments of the indebted nations. The IMF became the dominant emissary as it shifted its clientele from almost exclusively industrial countries to developing ones. By the mid I980s Latin Americans had become the main users of IMF financing (Bird 1996:477-480).

Who or what institution would undertake the ambitious task of constructing the new single market by promoting liberalism and transparency? Using new concepts, new vocabulary, and new indices, networks of professionals and managers have become the strategic emissaries enabling the new global relations. First, it must be said that the established agents of globalization have not abandoned the new global agenda. Established agents-representatives of the IMF, World Bank, AID, U.s. trade commissions, U.s. Secretaries and high officials of other core countries-active in the earlier phase of globalization, have taken up the new goal of market convergence. It's visible in their altered vocabulary and in the nature of their recommendations (a shift away from the 
development economics of earlier times). At the 1996 summit of oAs, for example, Amb. Babbitt asserted that "transparency [is] vital to u.s. businesses seeking to expand markets" (1996). Amb. Babbitt reports that the oAs unit for the Promotion of Democracy works to strengthen grassroots participation in the democratic process, to promote accountable government, and to create strong public institutions. Looking forward toward a Free Trade Area of the Americas by 2005 , the United States encouraged a dramatic liberalization of the economies in the hemisphere. Gershman, a NED official (National Endowment for Democracy), testifying to the House International Relations Committee in support of the Administration's $\$ 32$ million FY2000 request, said that it supports affiliate institutes that are dedicated to important goals such as the promotion of governmental transparency and accountability. In Latin American the NED supported programs which are furthering the "adoption of reforms intended to encourage government transparency and efficiency" (Gershman 1999:I,6). Another avenue has been the G-20, the extended organization of the G-8. In 2000, at the Montreal summit of the Finance Ministers from the G-20, there was a "renewed drive for economic globalisation" (Beattie 2000). Beattie reports that the Finance Ministers and central bankers from the G-20 have been satisfied with the success at increasing transparency in the adherence to international standards of fiscal and monetary policy and data dissemination, but they have also been surprised by the strength of opposition to economic liberalization, not only on the part of street protestors but also on the part of governments of some poor countries. In response to this threat to a liberalized economic order, they hope that the G-20 Ministers can function as a political counterpart to the technocratic groups. Those earlier agents remain crucial for the solvency of national banking systems, and certainly as collectors and disseminators of financial data.

As globalization got reconfigured, so too did the institutional pillars and agents that facilitated the global flows. Global flows are now guided by private rating agencies and investment companies in the capital-rich core nations, where one also finds the majority of the investors. ${ }^{16}$ The new emissaries include the bond raters such as Moody's and s\&p. Other participants generating and disseminating ratings include brokerage houses, financial consulting organizations, as well as magazines, all representing mutual funds, pension funds, insurance companies, and private investors. They are, Sinclair argues, embedded knowl-

16. In I990s, the United States held close to 50 per cent of the assets managed by such funds (Giron and Correa 1999). edge networks (EKNs) at the heart of contemporary global governance and are active in the debate about the reform of the international financial architecture (IFA) (200I:44I).

International capital flows are hardly new, but in the I990s many fund companies created new vehicles that allowed investors to specialize in FPEI investment in the Third World (Laderman 1993). In 1996, S\&P reported that it was responding to a growing demand from investors and financial institutions, and expanding its ratings on banks in emerging markets (Kraus 1996). King and Sinclair argue that Moody's and s\&p (with Fitch a distant third) dominate the market and that their oligopolistic position was reinforced by U.S. government regulations making it harder for new groups to launch ratings businesses (2003:348). Nevertheless, many other companies and organizations have joined the rating frenzy. Among the Latin-American sovereign raters, a number of firms are prominent. Fitch rates the foreign and local currency debt of sovereign governments, some 50 subnationals outside of the United States, mainly in Europe, but also in Latin America. DCR began its network in Latin American in the 1990s with local credit rating affiliates in Chile, Mexico, Peru, Venezuela, Argentina and Columbia. In 1996, it was the leading rating agency in Latin America, rating $87 \%$ of U.s. dollar structured financing originating from the region. SR was established as the first credit rating agency in Brazil in 1993 and its founding was lauded for good timing, opening soon after the "Real Plan" slashed inflation, and Brazilians became more aware of market risks (PR Newswire 1996). From 1996 to 2000, it participated in a partnership with DCR.

In the new global phase, it is appropriate to expand Sinclair's conception of EKN to include a wider range of organizations (profit and nonprofit) that generate indices. They are too numerous to mention but are exemplified by the financial consultant Multiplica (offering the judgment on Ecuador's liberalization); Investor Relations magazine in association with Bloomberg (bestowing awards on Latin American companies in recognition of excellence in their investor relations) (PR Newswire 2000); and S\&P (in 1999, it assigned its first rating ( $\mathrm{mxBBB})$ to a Mexican state, underscoring the strengthening credit culture developing in Mexico following its 1995 financial reform efforts) (Business Wire 1999). The public sector was not excluded. In 2002, CalPERS (the u.s.' largest public pension fund) completed its review of emerging markets announcing with whom it would allow investment of California's public equity. CalPERS considered a broad range of financial factors including transparency, political stability, and labor practices (Business Wire 2002c). It is believed to be the first evaluation ever undertaken by a public pension fund. These index-creators are joined by individuals from think-tanks, private research organizations, and academic institutions. 
In conclusion, the IMF, WB, and NED officials still have a role, but rating agencies such as S\&Ps, Moody's, Fitch, and Duff and Phelps Credit Rating (DCR) are now in the forefront assessing the investment risk of those stocks and bonds issued by the emerging markets ${ }^{17}$. As the emissaries shifted from the public quasi-governmental agents to the "market," the number and diversity of actors increased. They constitute a weakly linked international network of professionals and fund managers that engage in information gathering, dissemination, and monitoring functions. Their signals are available to both investors and to emerging markets. ${ }^{18}$ On the side of the emerging markets, the initial few capital-seekers, mostly the Latin-American federal governments, have been joined by a multiplicity of recipients, including private enterprises, state and municipal governments.

The analysis of vocabularies, routines, and emissaries bolsters the worldsystem explanation because it demonstrates continuity from a core need to a core conceptualization of the need. These were not just any superior theories, but they were tailored to specific core needs. There were not theories that could be promoted by any international organization, but they were promoted by emissaries tied to the nature of the core need.

\section{THE FRAME DISSEMINATED TO THE RECIPIENTS}

The content of the templates advanced by agents of core nations can shed light on the mechanism of convergence. The "compelling logic" specified by the world-culture model highlights the advantages of frame-adoption, such as productivity advantages or the enhancement of national legitimacy in the new global economy. In contrast, I have argued that the new frames (liberalism and transparency) were the unequivocal by-products of the new phase of globalization in the core. At the point of origin, the frames are universal-no restraints on foreign portfolio investment, for example. As these templates are disseminated to recipients, they become country-specific. They do not represent negotiated variations; rather, they measure an agent's assessment of each country's

17. $\mathrm{S} \& \mathrm{P}$, for example, has 5,000 employees located in I8 countries and provides data, research, and investment and credit opinions to global capital markets (Business Wire 2002b)

18. Sinclair demonstrates that these (EKNs) changed in nature and power following the financial volatility of the I990s (the I994-I995 tequila crisis, the I997-I998 Asian financial crises, and the I99os corporate and municipal collapses in the United States). The agencies spent more money on staff training and hiring, and became more public about the basis of their ratings (2001:447). deviation from the universal template. They also offer continuous feedback to nations and investors. Scores, these externally generated evaluations, are connected to enterprise and governmental actions.

\section{A New Kind of Scoring}

"Scoring" is certainly not new. Stocks historically have been rated so that potential purchasers have some idea of what they are buying and its likely profitability. From the I930s to the I980s, the Securities and Exchange Commission imposed standardization on information produced by corporations. In order to sell any issue in the United States, ratings were required (Sinclair 2001:445). The rating firms focused on higher-rated industrial firms in the United States. This focus was enlarged in the mid-rg8os when lower-rated companies were allowed to raise capital by selling debt on the bond market. Government bonds also have a long history of ratings. Each time a government entity announces the intent to issue a specific bond, it acquires a rating." [W] hen they enter the international capital arena... a rating is the first step in establishing a relationship with international investors....The credibility of that relationship must be maintained by good disclosure practices and ongoing discussion of the issuer's strengths and weaknesses" (PR Newswire 1997b). Ratings tell investors about a government's willingness and ability to service its debt obligations, the overall economy, pledged security, debt structure, financial condition, and statutory, constitutional, and legal factors. Creditworthiness is assessed with a standard that is comparative (at least for each brokerage house or rating agency) across emerging markets. The score, based on a risk model, can be used by subscribers to decide whether or not to invest. Despite this scoring tradition, the I99os was different. It was demarcated by the pivotal role of multiple and independent but equivalent emissaries (the EKNs), the content of the frames (scores), and the character of their disclosures (their frequency, quantifiability, and comparability).

\section{Country-Specific Interpretations}

Armed with the new agenda of creating a single financial market, the emissaries participate in specialized forms of intelligence gathering, judging, and reporting. How would this information be disseminated? Standard techniques of bond ratings continue. As more entities go to the bond market, more bond ratings are generated, but, these remain specific to the particular bond and issuer. A second set of ratings is disseminated in the form of indices and scales which have the characteristics of cross-country comparability. These ratings also appear with regularity, often annually. An investor has a plethora from which to 
choose (see Appendix A for some examples). Transparency International collects data, constructs and publishes two indices: a Bribery Propensity Index (вPI) and the Perceived Corruption Index (CPI). PricewaterhouseCoopers launched its O-Factor, the Opacity Index in 200I (Business Wire 200I). Based on the O-Factor, they generate two additional scores (for each of 35 countries). Since opacity will raise the cost of doing business, the organization has estimated that value calling it a 'Tax Equivalent'-the equivalent of an additional corporate income tax. Second, they generate an Opacity Risk Premium which indicates the increased cost of borrowing faced by countries due to their own opacity. Countries with higher opacity tend to have to pay a higher interest rate on the debt they issue. A study by PricewaterhouseCoopers (Opacity in Latin American countries) conjectured that some countries had foregone up to USD $\$ 40$ billion in FDI (the case of Brazil) as a result of the lack of transparency in their business practices. Their hope is that government regulators and policy makers in Latin America will use this tool to enhance transparency and stimulate their nations' economies. Such ratings are essential.

\section{Frames with Prophetic Edges}

The indices and scores are more than bundles of new ideas, cultural recipes, and superior theories, they are "mechanisms of persuasion." First, they signal how a country rates on a given standardized scale and allow both the investors and the recipients to make cross-country comparisons. Scoring is directed at national and municipal fiscal and monetary policies, and individual company policies and clearly links policies regarding transparency to the probability of investment. Second, they offer counsel and ultimatums outlining needed changes. And third, they forecast the positive (or negative) consequence of action. For example, "Approval of an austere budget and reform measures, designed to reduce budget deficit, could lead to a rapid upgrading of the local currency rating" (PR Newswire 1999b). And they offer post-reform praise. When Fitch upgraded its outlook of the Banco Rural of Brazil from ввв- to ввв, it was the result of Banco Rural's decision in 200 to replace its regional audit firm with a large renowned international company (Business Wire 2002a). These scores can be used by governments to judge how their actions of privatization, deficit reduction, and such are viewed by external investors.

But why should this be considered problematic, municipalities have had their bonds rated for over a century? For one, these private emissaries from core-nation have displaced public power in emerging nations. They advocate reforms that narrow the legitimate sphere for future state-led public policy interventions, while prescribing others. The consequence, Sinclair thinks, is
Table 3 - Sample Indices Evaluating Brazil and Select Countries*

\begin{tabular}{lclll}
\hline & Brazil & Chile & Mexico & USA \\
\hline Growth Competitiveness Index Ranking 2003 & 54 & 28 & 47 & 2 \\
Opacity Index (2001) & 60.85 & 35.65 & 47.65 & 35.53 \\
Tax Equivalent (2001) & $25 \%$ & $5 \%$ & $15 \%$ & $5 \%$ \\
Opacity Risk Premium (2001) & 645 & 3 & 308 & 0 \\
Corruption Perceptions Index (2002) & 4.02 & 7.5 & 3.6 & 7.7 \\
Corruption Perceptions Index (1997) & 3.56 & 6.05 & 2.66 & 7.61 \\
\hline
\end{tabular}

Note: See Appendix A for detail on these and other indices.

deeply worrying (200I:44I-449). In a world of fast-paced market developments, it is increasingly hard for governments to cope. Many of them seem inclined to give up. In Block's view (1996), countries will be subjected to the dictatorship of the international financial markets.

\section{Brazil Receives Country-specific Frames with the Prophetic Edge}

The three aspects are present in the frames disseminated to Brazil. First, Brazil is scored in a fashion that allows investors to judge the progress being made (of the country, company, bank, state, or municipality). A few of Brazil's scores are compared with other countries in Table 3. Second, the frames prescribe reforms, and third, they enumerate the consequences of responding to these recommendations. The scores, the prescribed reforms, and the payoffs constitute a trinity evident in the quotes selected from various sources.

"We are very impressed with the Cardoso administration's success in controlling inflation." Fergus McCormick, a DCR analyst who covers Brazil continued, " $[R]$ eassuring the markets, however, will require more fundamental reform particularly of the constitution, the civil service, and the pension system" (PR Newswire 1997b). Two years later DCR's McCormick wrote: "The progress that Brazil has made in adhering to the IMF-sponsored adjustment program, though it largely involved one of tax and privatization measures, represents a stride forward in fiscal consolidation.... However, a local currency rating upgrade would hinge on adherence to the austere 2000 federal budget and on progress in tax and social security reform" (PR Newswire 1999a). Raters complained of Brazil's current account deficit (it was $3.8 \%$ of GDP at the end of 1999), high social security benefits, and a bloated public-sector (PR Newswire 1999c). Observers 
praised the "progress in controlling inflation, high foreign direct investment, and Brazil's diversified private sector," but what they didn't like was the "large domestic and external debt burden, social pressures and the political environment" (PR Newswire 1999). In fact, they felt that Brazil lacked the political commitment to reduce government overspending.

In lamenting the precipitous drop in the Bovespa index which was caused by capital migration to safer havens, the managing director with Banco Chase Manhattan in Sao Paulo said that "government and market players must work together to improve transparency, strengthen minority shareholder rights, eliminate financial transaction taxes as well as restrictions on domestic investment funds..." (Colitt 2000).

The analysis of the country-specific versions of standard templates reinforces the claim of the world-system explanation on several grounds. Almost all of the explanatory models invoke some aspect of cross-national contacts. In the world-polity account of diffusion, common memberships in international professional organizations might expose actors to the notion that having a Ministry of Education is a "good thing." Or in looking more closely at their peers, they might see that more legitimacy is accorded to nations who have a Ministry of Education. In either case, they might receive ideas and outside help in setting up such a Ministry. However, the identification and role of the emissaries are less theorized. This is in contrast to the world-system perspective which identifies the embedded progression from the original investment needs of the core countries, to the universal frames of transparency and liberalization, and to the interpretation and transmission into country-specific scores and prescriptions.

\section{DEGREE AND NATURE OF LINK}

\section{The "Emerging Market" Responds to the Ultimatums}

In contrast to core-core diffusion, diffusion from core nations to semiperipheral or peripheral ones may appear more puzzling. Stated from the perspective of the individual adopters, why do developing nations embrace international neoliberal standards, especially where that embrace sometimes produces consequences that are at odds with extant national policies and political authority. Haggard and Maxfield point out the irony that some developing countries embarked on "premature and ill-conceived liberalization efforts" even before advanced industrial states (1999:35). In the world-system model the agents and adopters are more tightly and visibly linked. The country-specific scores reflect the core's vested interests in emerging markets. These tailored prescriptions continually shift based on actions taken and/or progress made. This converts country-specific descriptive scores into country-specific ultimatums.
Table 4 - Gross Domestic Savings Rate as Percent of GDP

\begin{tabular}{lllll}
\hline & Brazil & Latin America & Mexico & OECD \\
\hline $\mathbf{1 9 9 0}$ & 21.40 & 21.46 & 22.04 & 23.21 \\
1995 & 20.52 & 20.38 & 22.48 & 22.25 \\
1999 & 19.33 & 19.16 & 21.94 & 22.57 \\
\hline
\end{tabular}

Source: World Bank. 2001. World Development Indicators. CD-ROM.

Latin American nations and firms are compelled to respond to country-specific ultimatums, not generalized frames. Capital-poor countries in need of these capital flows are compelled to align their financial market structures with those guidelines offered by the rating and brokering houses.

The other side of the tight link is the capital need of emerging markets. The fact that growing amounts of liquid assets are held in private funds in developed nations links the two sides together. But why is there such a need? Despite the apparently favorable savings rate (Table 4), Brazilian politicians and commentators continued to express interest in raising capital. Commentators observe that banks are experiencing a capital shortage and their "customers are experiencing a severe liquidity squeeze, and industrial investment can be expected to shrivel..." (Cambridge International 1999). That Cambridge International commentator was particularly worried about capital flight from emerging markets, from Brazil in particular, and the ominous prospects for merchant banking activity. In 200I, Osorio argued that Brazil needed new legislation to reform the country's equity market. He reported that, following a 1976 corporate law, Brazil made reasonable progress in attracting retail savings to fund Brazilian corporate groups, but that there was a shortage of capital flowing to the capital markets. Also in 200I, the Banco do Brasil (Central Bank) expressed interest in raising capital by putting some of its shares up for sale. ${ }^{19}$ The 2004 Bovespa Annual Report began with "Brazil certainly needs foreign investments...for the last ten years, foreign investors have accounted for at least $25 \%$ of the trading volume. In 2004, foreign investments accounted for $27.3 \%$ of the trading volume" (Bovespa 2004).

19. The Bank anticipated listing up to $22 \%$ of its stock on the Sao Paulo Stock Exchange and it noted, Bovespa is reserved for companies with the highest level of transparency (O Globo 200I). 
Thus availability on the supply side, meets capital needs on the demand side. The matchmakers are the agents described above. This need of emerging markets helps us to understand why country-specific scores and indices have the power of persuasion. Furthermore, Latin Americans realized that they are competing with other emerging markets (Asia, Eastern Europe, and etc.) and will only succeed in capturing and holding the capital needed to enhance economic growth if they follow the suggested frames and templates. ${ }^{20}$ Simmons and Elkins demonstrate that competitive pressure among peer policy makers is crucial in understanding policy liberalizations, but they identify "peer" countries on very different criteria. They suggest that one of the learning mechanisms is to look at the policies of their respective cultural reference group (religion, colonial, or language partners) (2004:173-177). Their "country competition" and "cultural peers" variables pool together nations that a world-system theory would not. Importantly, it is the core agents, not necessarily emerging market policy makers, who are constructing the comparative set. Forbes, for example, evaluated the late September 1998 opportunities for investors by comparing Brazil's economic problems with those of Russia (Eaton 1988). In 1996, the Wall Street Journal compared Sao Paulo's stock market, Bovespa, with Amsterdam's ANP-CBS General in the Netherlands, Argentina's Merval Index, and Hong Kong's Hang Seng. In other words, the grouping generated by S\&P and others looks very different from those constructed in world-culture models where the comparisons are identified as countries similar in region, in levels of development, in trade patterns, and the like (Simmons and Elkins 2004).

Some authors argue that the diffusion process is one of consensus because countries have chosen this path. Countries choose to solicit international capital and are therefore constrained to adhere to those conditions. Although not included in the sequence developed here, the world-system perspective also offers a theorization of why some peripheral and semiperipheral nations are faced with capital shortages. Second, the constraints in question are not idiosyncratic or unexpected, they are derivable from a world system perspective that identifies the investment needs of the core and connects them to the capital needs of Brazil.

20. Following the 1997 market crash in Asia, emerging market debt funds flocked to Latin America and pulled out of Europe, Asia, and the Middle East (Emerging Market Debt Report 1998).

\section{Consensus or Consent?}

The involvement of Brazilian politicians and economic elites also might lead us to conclude that consensus is the operative mechanism. But, there is a long tradition of domestic actors embracing exogenous institutional forms. They have gone under various names from the colonial-criollos (Brazilian born Portuguese who continued the work of the empire), to modern-day "technicos" (Centeno 1998), and global elites (Robinson 2002:1056). Fourcade-Gourinchas and Babb even characterize the local elites who ushered in the neoliberal policies as a social movement. In Chile, they were organic intellectuals of the bourgeoisie who opposed Allende's rule in Chile (2002:542), whereas in Mexico, they were insiders-bureaucrats who saw international financial pressures as an opportunity to advance both their political careers and their particular ideological program (2002:557). In these and many other cases, the locals have graduate degrees from foreign (core) universities. Since both the consensus and consent models allow for domestic carriers of new exogenous templates, citing the "nationality" of the promoters does little to distinguish them. Instead, I have distinguished the consensus model from the consent model on the basis of the five elements: origin, frames offered in core, agents, frames offered to emerging market actors, and linkages.

\section{CONCLUSION AND DISCUSSION}

For emerging markets, the mode of operation must change. The privatization process must continue and the financial operations must operate in a "transparent" fashion. I have argued that "consenting under constraints" is a more reasonable interpretation of the diffusion process than "consensus" in terms of providing a superior model. The notion of "coercion" still engenders resistance, perhaps because the concept of authority/power is viewed principally from the Weberian perspectives of tradition, legal-rational, or charisma (Stinchcombe 2003:429). Despite the presence of multiple agents (who do not exercise force) they represent and enforce the exigencies of a new globalization. Why has there been less attention to the possible coercive aspect of the convergence process? One answer might be methodological, namely that the very evidence of a global diffusion of some institutional forms gives plausibility to the conclusion that a superior model gained consensus and was voluntarily adopted by a large number of recipients. A second reason for the popularity of a model such as world-culture is that ironically, diffusion researchers have detected core-practitioners applying a basic postulate-“"TT]he more demanding requirements of compliance-oriented information systems will make them less common than effectiveness-oriented systems" (Mitchell 1998:115). Strang 
and Meyer suggest that "theorization helps innovation masquerade as diffusion" (1993:500). Following Mitchell, I would say that theorization helps consent masquerade as consensus. How else could Michael Lewis write after September II, 200I that "bond traders are as critical as the U.S. generals and the politicians to extending liberty's influence in the world" (NYT 200I)?

It may be that the consent/coercive mechanism is sector and period-specific. Perhaps for mass education, human rights, and other arenas distant from global capitalism, consent and dependency relationships are less relevant. In the global phase dominated by trade, for example, the world was integrated despite colossal county-level variations. A world-system perspective permits two observations regarding this new phase of globalization. First, financial flows are not free floating. Rather, they are stewarded by new agents with new organizational routines. Second, countries do not voluntarily adopt universal forms because those templates are superior or offer national legitimacy. Their dependent status leaves them little choice. The diffusion literature borrows some of the components of a world-system analysis, but without the essential concepts of that perspective. ${ }^{21}$

\section{Beneficial or Harmful?}

Negative repercussions of these exogenously generated reforms might be used to refute the "consensus" model. As Meyer et al. comment, it is truly puzzling why nations should engage in "structural isomorphism in the face of enormous differences in resources and traditions...to serve purposes that are largely of exogenous origins" (1997:I45). This counterfactual strategy might augur badly for the consensus model-if introduced reforms continually produce negative consequences, the notion of a more efficient or superior model would be put into question. However, the claim of consent/coercion cannot be synonymous with a claim that the outcome is harmful. Reforms might be in the best interest of emerging markets regardless of the mechanism. Or, local elites in emerging markets may not be in the best position to appreciate the long-term benefits of the reforms, or they might need the assistance of international pressure to

21. Although the main mechanisms include network relations, learning from others, and cultural factors (Strang and Meyer 1993:488-490), they have added "exchange dependence." A reader might contend that they have anticipated my argument and that I have created a straw-man version of the diffusion model. But my argument-that the transformation of the world-system and its dependency relations are the primary driver of the convergence-differs from a model where a measure of "exchange-dependence" is added to increase (or not) the variance explained. overcome domestic resistance to the reforms. In short, the diffusion mechanism-consensus or consent-must be separated from the outcome.

The benefits of financial openness for core nations are clear. What about the benefits to emerging markets? Contrary to their assertions, capital suppliers (investors) are not "entitled" to privatization (that nation-states offer them shares in their national banks, for example). However, they are entitled to information that assesses the risk of offered investments, and to reasonable guarantees regarding those investments. And, for emerging markets, reforms that reduce pilfering of public and private funds will contribute to economic growth. Recapping the conventional wisdom, Firebaugh writes that nations with secure property rights, effective legal system, and less distortionary government policies will tend to grow faster (2003:195). Much of the research demonstrates the positive consequences of financial openness which results in increased capital flows. ${ }^{22}$ Evidence of benefits also is cited in country-specific reports. An Argentine insurance agency "amended its past errors" and was, the report claimed, on the verge of showing profits for the first time in years (Business Wire $2002 \mathrm{~b}$ ). The adoption of superior templates and the restructuring of governance and reporting structures may increase efficiency of firms or governmental units. Perhaps convergence will bring growth and development. Perhaps the promises made (yet never fully realized) for open markets and for foreign direct investment will finally show fruition with a single global capital market.

But there are also concerns. Morgan of the Financial Times wrote that there was plenty of transparency in the recent Asian crisis, and everybody knew what was going on. The wealth of information, he says, acted as "a red rag to a bull market" (1998). In Latin America, concerns also have been expressed regarding the negative economic consequences of these reforms. Privatization in Brazil, for example, netted the state only a small portion of the market value of firms. And, with the period of large sales of state assets over, there was less lucrative work for banks that coordinated these deals for multimillion dollar fees (Romero 2002). This in turn, left less-attractive targets for outside investors, and less capital for the state to invest in growth-promotion projects. In response to this volatility, "President Cardoso announced in September of 1998 that he was stopping short-term capital flows, in a move designated to restrict the scope for speculators and hedge fund operators" (Cambridge International 1999). Others expressed concern that the high interest rates required to attract

22. Quinn and Inclan (I997) offer an extensive summary of the scholarship on consequences, both the positive and negative. 
foreign capital (40\% a year in 1998) would act as a brake for middle classes consumers who could no longer afford the items that they had previously bought (Cohen 1998). On balance, the reforms to minimize capital account regulation have supporters and critics. The highlighting of negative consequences might not be sufficient to refute the consensus model, but it certainly lends support to the notion of consent.

\section{The Remaking of Dependency Relations and the "Lula-Meter"}

From a world-system perspective, dependency relations have been recast. The term "dependency" has always implied more than poverty or harmful effects of adopting exogenously developed organization forms. It suggests that decisions made exogenously about domestic rules and norms, and adopted under pressure from agents who present them as quid-pro-quo for receiving foreign capital flows, may negatively affect economic development, social welfare, and political sovereignty.

This goes beyond the negative consequences described above. Scholars have identified the fiscal and monetary problems associated with increased capital account liberalization and its impact on the state's ability to administer its industrial policy, maintain political patronage, and finance its own activities (Haggard and Maxfield 1999). Rodrik amplifies the trilemma of international economic integration (that a country cannot simultaneously maintain independent monetary policies, fixed exchange rates, and open capital accounts) to a political trilemma (a country cannot simultaneously have international economic integration, strong nation-state, and mass politics) (2000:180). The ability to promote general social welfare and, therefore, democratic legitimacy has typically depended on a sovereign and viable nation state, but the new globalization has led to what Stoper calls the "deterritorialization of economic power" (1997:32), and what Evans calls the "eclipse of the state." While the cold war may have required an international system of nation-states, the new global system does not. And, the shift was accompanied by a series of new arguments about why states are anachronisms. Evans contends that the particular aspects of the new global economy that provided rationales for low "stateness" include the increasing weight and changing character of transnational economic relations, and the growing global hegemony of an Anglo-American ideology regarding the rules of economic engagement (1997:63-65). In this environment, Stinchcombe views nation-states as a source of "solidarity," which in any form is a barrier to capitalism because for capitalism to spread, so too must its logic (2003:413). All authors recognize that the eclipse rhetoric refers to nation-states exercising their traditional roles (industrial policy, redistribution, and etc.), and that nation-states still remain crucial for facilitating international capital flows.
Dependency relations, consolidated through capital flows, threaten to affect the legitimacy of Brazil's democracy. With the increasing integration of Brazilian municipalities into the global financial markets, unelected and "noncitizen" actors (foreign investors) become participants in domestic politics and public policy. "Who elected the bond raters" is an updated version of Pauly's question "Who elected the bankers" (1997). Raters, who represent speculative capital movements with short-term financial considerations, and who will never have to live with the social or political consequences, pass judgment on everything ranging from the Brazilian Constitution to municipal welfare spending. They rendered judgments on the 2002 presidential election. ${ }^{23}$ The EKNs used their statistical indices to weigh in when it appeared that the candidate from the PT (Workers' Party) might win: Merrill Lynch and Morgan Stanley Dean Witter shifted their recommendations; Brazilian Brady bonds dropped sharply, as the $\mathrm{C}$-bond traded below 80 per cent of face value early that week; the country risk, as measured by the JP Morgan emerging market bond index, rose to 825 points (a month earlier ago, the index was near 700 points); and Goldman Sachs created a "Lula-meter," a mathematical model designed to evaluate how much the markets had "figured in" the probability of a Lula victory. In the period just prior to the election, these statistical sermons were accompanied by punitive actions. Citigroup cut its Brazilian exposure selling off, as did Bank of America. The speed with which many banks pulled back, or even left the country, was a surprise to many Brazilians (Romero 2002). The Wall-Street "candidate" did not win the 2002 Presidential election. Nevertheless, the international pressure to reduce social expenditures, reform social security and the like, have left the elected President Lula de Silva with reduced degrees of public-policy freedom.

The potential for democratic instability is latent in contradictory mandates received by President Luiz Inacio Lula da Silva. Financial openness produces macroeconomic policies that are often at odds with programs mandated by electoral supporters (Quinn and Inclan 1997:773). As a member of the PT,

23. George Soros was reported to have said at a dinner offered by the Council on Foreign Relations "In Rome, only the Romans voted, in modern global capitalism, only Americans vote, Brazilians don't vote." Reported in the Brazilian newspaper, "Folha de S. Paulo," the comment was in reference to the upcoming Brazilian presidential election in which Soros believed that Brazil had to elect the candidate Serra over Lula da Silva (who was elected). If candidate Jose Serra was not elected, Soros predicted, the country would drown in chaos, and the financial markets would retreat. This, commented the reporter, is absolutely antidemocratic in the sense that the threat impedes theoretically sovereign electors from choosing the candidate that they prefer (Rossi 2002). 
he was elected because he campaigned on the need to give a higher priority to the social needs of the citizenry. ${ }^{25}$ As President of an "emerging market," he must respond to the global investors. Given the orchestrated pressure emanating from the rating houses in the developing countries and the capital needs of emerging markets, Latin American nations have limited choices but to accept the conditions attached to those global portfolio flows. The fact that Brazil resists some of the recommendations (or that there is variation) does not challenge the "consent" argument. To the contrary, the very push and pull is more typical of coercion than consensus.

While the notion of a world-culture filled with superior ideas and frames, adopted by independent nations, is an attractive one, it misses much of the way in which this new phase of globalization has unfolded. Globalization is a euphemism for the current restructuring of the international economy (Klak 1998). The world-systems approach allows us to theorize the phases of economic change, the causes of paradigm shifts, the dissemination of new paradigms by new emissaries, and their potential punitive capacities. Brazilians have embraced liberalism and transparency, but this new globalization has not altered one basic process: the relationship between the developed nations and the developing ones still has a component of dependency.

\section{REFERENCES}

Anheier, Helmut, Marlies Glasius, and Mary Kaldor. 200I. "Introducing Global Civil Society." http://www.lse.ac.uk/Depts/global/Yearbook/PDF/Ch1.pdf [URL Inactive as of $\mathrm{II} / \mathrm{I} 7 / 2006]$

Arrighi, Giovanni. "Global Inequalities and National Development: Pernicious Postulates, Unsolved Puzzles." Paper presented at the 96th Annual Meeting of the American Sociological Association. Anaheim, CA, August I8-2I, 200I

Azevedo, Simone. 200I. "Balancos se Sofisticam para Atrair Investidor Estrangeiro." [Balance Sheets get more sophisticated to attract foreign investors]. Gazete Mercantil 5 June.

24. As one voter put it "I know that there is much pressure on Lula to cut our pensions... But many people like me voted for him because we felt the previous government paid too much attention to the bankers and the business community and ignored the needs of the poor and the ordinary workers. We voted for him because we see Lula as one of us and if he cuts our pensions, many of us will be very, very disappointed in him" (Jeter 2003).
Babbitt, Harriet C. Ambassador. 1996. Prepared Statement by Ambassador Harriet C. Babbitt United States Permanent Representative to the Organization of American States Before the House Appropriations Committee Commerce, Justice, State, and Judiciary Subcommittees. Federal News Service 2 May.

Beattie, Alan. 2000. "G20 urged to support economic globalisation." Financial Times October 23.

Bird, Graham. 1996. "The International Monetary Fund and Developing Countries." International Organization 50 (3): 477-5II.

Blanke, Jennifer, Fiona Paua, and Xavier Sala-I-Martin. 2004. "The Growth of Competitiveness Index: Analyzing Key Underpinnings of Sustained Economic Growth." Chapter I.I in Global Competitiveness Report. World Economic Forum. 2004. http://www.weforum.org/pdf/Gcr/GCR 2003 2004/Competitiveness Rankings.pdf.

Boli, John and George M. Thomas, Eds. 1999. Constructing World Culture: International Nongovernmental Organizations since 1875. Stanford: Stanford University Press.

Block, Fred L. 1996. The Vampire State. New York: The New Press.

Bovespa. 2004. "Brazil's Stock Exchange: Bringing in Investments for the Growth of Brazilian Companies." Annual Report BOVESPA2004.

Burawoy, Michael. I99I. Ethnography Unbound. Berkeley: Univ. of California.

Business Wire. 2002a. Brazil. "Fitch Upgrs Banco Rural's Nat'l Scale L-T Rtg; Outlook Changed to Stable, From Evolving." I7 April.

Business Wire, 2002b. "S\&P Report on Argentine Insurers' Challenges.” II March.

Business Wire. 2002c. "CalPERS Adopts New Model for Investing in Emerging Markets." 20 Feb

Business Wire. 200I. "Opaque Economic and Business Practices Cost Individual Mercosur Countries Up to usD \$40 Billion in Foreign Direct Investment According to PricewaterhouseCoopers Study." 20 May.

Business Wire. 1999. "Neuvo Leon First Mexican State to be Rated by S\&P." 20 December.

Calvo, Guillermo A., Leonardo Leiderman, and Carmen M. Reinhart.1996. "Inflows of Capital to Developing Countries in the I990s." Journal of Economic Perspectives Io $(2): 123-I 39$.

Cambridge International. I999. "Brazil: Economy." Janet Matthews Information Services, Quest Economics Database, in Lexis-Nexis Academic Universe, I7 Nov. http://web.lexis.nexis.com

Canterbery, E. Ray. 2000. Wall Street Capitalism: The Theory of the Bondholding Class. Singapore: World Scientific.

Carruthers, Bruce G and Wendy Nelson Espeland. I99I. "Accounting for Rationality: Double-Entry Bookkeeping and the Rhetoric of Economic Rationality." American Journal of Sociology 97 (I): 3I-69. 
Carneiro, Dionisio Dias. 1998. "Capital Flows and Brazilian Economic Performance." PP. 77-109 in Capital Flows and Investment Performance: Lessons from Latin America, Ricardo French-Davis and Helmut Reisen (Eds) U.N. Economic Commissions for Latin America.

Centeno, Miguel and Patricio Silva. Eds. 1998. The Politics of Expertise in Latin America. New York: St. Martin's Press.

Coffee Jr., John C. 2002. "Racing towards the Top? The Impact of Cross-Listings and Stock Market Competition on International Corporate Governance." Columbia Law Review I02 (7): 1757-I831.

Cohen, Roger. 1998. "Brazil Pays to Shield Currency and the Poor see the True Cost." New York Times, 5 Feb.

Colitt, Raymond. 2000. "Foreign Exodus Weakens Brazil Market Focus.” Financial Times Oct I3.

Colitt, Raymond. 1995. "Survey of Ecuador." Financial Times 27 July.

Dicken, Peter. 1992. Global Shift. London: Paul Chapman Publishing Ltd.

Dornbusch, Rudi. I996. "Brazil Has Run Out of Excuses." Business Week ro ro June.

Drucker, Peter. I99I. "Reckoning with the Pension Fund Revolution." Harvard Business Review (March-April.):106-II4.

Eaton, Thomas. I988. Forbes. I62 (7):54-55, 5 October.

Economist. 1993. "Clean, not Laundered." 8 May.

Emerging Markets Debt Report. I998. "EM Debt Funds Sell Off in the Forth Quarter" April 20.

Evans, Peter. 1997. "The Eclipse of the State? Reflections on Stateness in an Era of Globalization." World Politics 50 (I): 62-87.

Feldstein, Martin. I995. "Too little, not too much - Global Capital Flows." Economist 24 June.

Fligstein, Neil. 200I. The Architecture of Markets. Princeton: Princeton University Press.

Firebaugh, Glenn. 2003. The New Geography of Global Income Inequality. Cambridge: Harvard University Press.

Fourcade-Gourinchas, Marion and Sarah L. Babb. 2002. "The Rebirth of the liberal Creed: Paths to Neoliberalism in Four Countries." American Journal of Sociology I08 [3]: 533-79.

Garcia, Marcio G.P. and Marcus Vinicius F. Valpassos. 2000. "Capital flows, Capital Control, and Currency Crisis: The Case of Brazil in the I990s." PP. I43-I9I in Capital Flows, Capital Controls, and Currency Crises in Latin America, Felipe B. Larrain. Ed. Ann Arbor: University of Michigan Press.

Gershman, Carl. 1999. "Prepared Statement of Carl Gershman President National Endowment for Democracy Before the House International Relations Committee International Operations and Human Rights Subcommittee." Federal News Service 4 March.

Giron, Alicia and Eugenia Correa. 1999. "Global Financial Markets: Financial Deregulation and Crisis." International Social Science Journal 50 (I60): I83-I94.
Global News Wire 200r. "Regulator to Study Brazil's Comparative Rate SystemChile." 3 July.

Global News Wire. 1999. "PETROBRAS Aims to be 'Transparent', says DirectorRPT." I8 Oct.

Global News Wire. 1998. "Current Events Briefs." 5 January.

Goertz, Gary and Paul F. Diehl. I992. Toward a Theory of International Norms: Some Conceptual and Measurement Issues." The Journal of Conflict Resolution 36 (4): 634-664.

Guillen, Mauro F. 200I. The Limits of Convergence. Globalization and Organization Change in Argentina, South Korea, and Spain. Princeton: Princeton University Press.

Haggard, Stephen and Sylvia Maxfield. I999. "The Political Economy of Financial Internationalization in the Developing World." International Organization 50 (I):35-68.

Halliday, Terrence and Bruce Curuthers. 2003. "Globalizing Law: Political Influence in the Legal Construction of Markets by the United Nations Commission on International Trade Law." Paper presented to ASA August 2003.

Heritage Foundation. 2004. "Index of Economic Freedom."

International Federation of Accountants. 200I. GAAP2001 Report.

Jang, Yong Suk. 2003. "The Global Diffusion of Ministries of Science and Technology." In Science in the Modern World Policy. Drori, Gili S., John W. Meyer, Francisco O. Ramirez, Evan Schofer. Stanford: Stanford University Press. I20-I35.

JCR-VIS. 2006. "JCR-vis Credit Rating Company Ltd. Joins Regional Rating Agencies to Form International Rating Group." 23 February.

Jeter, Jon. 2003. "Pension Reform Tests Brazilian President; Cutting Large Payments Could Help Economy but Hurt Workers Whose Votes Put Lula in Office." Washington Post March 03.

Kearney, A.T. 2004. "Measuring Globalization: Economic Reversals, Forward Momentum." Foreign Policy Magazine. http://www.foreignpolicy.com

King, Michael. R. and Timothy J. Sinclair. 2003. "Private Actors and Public Policy: A Requiem for the New Basel Capital Accord." International Political Science Review $24(3) \div 345-362$.

Klak, Thomas. 1998. "Thirteen Theses on Globalization." Chapter I in Thomas Klak. Ed. Globalization and Liberalization: The Carribean Context. Latham MA: Rowman Littlefield Publishers.

Kogut, Bruce and Gordon Walker. 200I. "The Small World of Germany and the Durability of National Networks." American Sociological Review 66:317-335.

Kraus, James R. 1996. "s\&p to Rate More Banks in Developing Countries" The American Banker 26 December.

Laderman, Jeffrey M. I993. "Mutual Funds are Fat and Investors are Happy." Business Week II Oct.

Lewis, Michael. 200I. "Why You?" New York Times 23 Sept. 
Martinelli, Alberto. 2005. "From World System to World Society?" Journal of WorldSystems Research xI(2): 24I-260. http://www.jwsr.org

McLeod, Kirsteen. 1993. "Getting in on Emerging Action: Mutual funds can ease the way." Financial Post (Toronto, Canada) I5 December.

Meyer, John W, John Boli, George M. Thomas, and Francisco O. Ramirez. I997. "World Society and the Nation-State." American Journal of Sociology I03 (I): I44-I8I.

Miniane, Jacques. 2004. "A New Set of Measures on Capital Account Restrictions." IMF Staff Papers $5 \mathrm{I}(2)$

Mitchell, Ronald B. 1998. "Sources of Transparency: Information Systems in International Regimes." International Studies Quarterly 42: 109-I30.

Morgan, James. 1998. “The Lemmings Called Lenders.” Financial Times II July.

O Globo. 200I. "Treasury Considers Selling up to $22 \%$ of Banco do Brasil." Financial Times Information. 2I Nov.

Osorio, Jose Luiz. 200I. "Committed to Reform." LatinFinance November.

Pauly, Louis W. 1997. Who Elected the Bankers? Surveillance and Control in the World Economy. Ithaca: Cornell University Press.

Picciotto, Sol and Jasen Haines. 1999. "Regulating Global Financial Markets." Journal of Law and Society 26 (3): 35I-368.

PriceWaterhouseCoopers. "Opacity in Latin American Countries."

PR Newswire. 200I. "New Survey Highlights Significant Differences Between National Accounting Requirements and International Accounting Standards." Dec. II.

PR Newswire. 2000. "Investor Relations Magazine Announces the Best in Latin America IR." Io October.

PR Newswire. I999a. "Stable Brazil Outlook Explained in New DCR Report." 2 November.

PR Newswire. I999b. “DCR Reaffirms Brazil’s 'BB-' Sovereign Debt Rating.” 23 August.

PR Newswire. I999c. "DCR Assigns 'BB-' Rating to Brazil's eur70o Million Bond." 9 July.

PR Newswire. 1999d. "Global Investors Attracted by Transparency of International Companies." I4 June.

PR Newswire. 1997a. "Brazil's Problems Continue, but Rating Remains at 'BB-:" I4 November.

PR Newswire. I997b. "Local Governments Will be Active Players in International Markets, Duff \& Phelps Credit Rating Co. Says." 9 September.

PR Newswire. 1996. "DCR Inaugurates Joint Venture in Brazil." 3 December.

Quinn, Dennis P. and Carla Inclan. 1997. "The Origins of Financial Openness: A study of Current and Capital Account Liberalization." American Journal of Political Science 4I (3): 77I-8I3.

Robinson, William I. 2002. "Remapping development in light of globalization: from a territorial to a social cartography." Third World Quarterly 23(6): 1047-I07I.
Rodrik, Dani. 2000. "How Far Will International Economic Integration Go?" Journal of Economic Perspectives I4 (I): I77-I86.

Romero, Simon. 2002 “As Foreign Banks Take Flight, Brazil Regroups.” New York Times 15 Dec.

Ross, Robert J.S. and Kent C. Trachte 1990. Global Capitalism: The New Leviathan Albany: SUNY Press.

Rossi, Clovis. 2002. "Mercado impora Serra ou o caos, preve Soros." Folha de S. Paulo May I.

Salamon, Lester 2004. "How healthy is your civil society sector?" Alliance. I June.

Schwartzman, Kathleen C. 2004. Chapter 6. Globalization: The New Mechanism of Dependency. in Globalization, Hegemony and Power. Antisystemic Movements and the Global System. Thomas Reifer. Ed. Boulder: Paradigm Publishers: IIo-I30.

Schofer, Evan and Marion Fourcade-Gourinchas. 200I. "The Structural Contexts of Civic Engagement: Voluntary Association Membership in Comparative Perspective." American Sociological Review 66:806-828.

Simmons, Beth A. 1998. "State Authority and Market Power." Mershon International Studies Review 42: 135-I39.

Simmons, Beth A and Elkins. 2004. "The Globalization of Liberalization: Policy Diffusion in the International Political Economy." American Political Science Review 98 (I): I7I-I89.

Sinclair, Timothy J. 200I. "The Infrastructure of Global Governance: QuasiRegulatory Mechanism and the New Global Finance." Global Governance 7:44I-45I.

Strang, David and John Meyer. 1993. "Institutional Conditions for Diffusion." Theory and Society 22:487-5II.

Strange, Susan. 1996. The Retreat of the State: The Diffusion of Power in the World Economy. Cambridge: Cambridge University Press.

Stinchcombe, Arthur L. 2003. "The Preconditions of World Capitalism: Weber Updated." Journal of Political Philosophy II:4I I-436.

Stoper, Michael. 1997. "Territories, Flows, and Hierarchies in the Global Economy." in Spaces of Globalization Kevin Cox, ed. London: Guilford Press 19-44.

Survey-Global Custody. 1996. Financial Times 26 November.

Transparency International. 1997-2002. "Corruption Perceptions Index."

U.S. Department of Commerce. Bureau of Economic Analysis (BEA). 2002. "International Transactions Accounts."

Useem, Michael. 1996. Investor Capitalism. New York: Basic Books.

Vilela, Bruno Guedes. 2005. "O Novo Mercado e a Governanca Corporative no Brasil." Azevedo Sette Advogados November 8.

Ward, Stephen. 1992. “Top Banker Welcomes China Move." South China Morning Post 8 Oct.

Wheatley, Jonathan. I995. "Brazilian exchanges call for softening of controls." Financial Times August I6.

Wilensky, Harold L. 2002. Rich Democracies. Berkeley: Univ of California Press.

World Bank. 200I. World Development Indicators. CD-ROM. 
Appendix A - Selection of Indices

\begin{tabular}{|c|c|c|c|c|c|}
\hline & & $\begin{array}{l}\text { Founded } \\
\text { [or Year 1] }\end{array}$ & $\begin{array}{l}\text { Unfavorable } \\
\text { Score }\end{array}$ & Good score & Source/ Brief description \\
\hline CPI & $\begin{array}{l}\text { Corruption } \\
\text { Perceptions Index }\end{array}$ & 1993 & $\begin{array}{l}\text { '0' highly } \\
\text { corrupt }\end{array}$ & $\begin{array}{l}\text { ' } 10 \text { ' highly } \\
\text { clean }\end{array}$ & Transparency International \\
\hline $\mathrm{GCl}$ & $\begin{array}{l}\text { Growth } \\
\text { Competitiveness } \\
\text { Index }\end{array}$ & 2001/2002 & $\begin{array}{l}102 \text { [ranked } \\
\text { worst -based } \\
\text { on number of } \\
\text { countries] }\end{array}$ & $\begin{array}{l}1 \text { [ranking } \\
\text { most } \\
\text { competitive] }\end{array}$ & $\begin{array}{l}\text { Evaluates factors that will contribute } \\
\text { to growth: environment, institutions, } \\
\text { policies, technology, and structures. } \\
\text { Based on Data and Executive Opinion } \\
\text { Survey. World Economic Forum. Jeffrey } \\
\text { Sachs \& John McArthur (Blanke 2004). }\end{array}$ \\
\hline GCS & $\begin{array}{l}\text { Global Civil } \\
\text { Society Yearbook }\end{array}$ & 2002 & $\begin{array}{l}\text { multiple } \\
\text { scores }\end{array}$ & & $\begin{array}{l}\text { Evaluation of infrastructure needed to } \\
\text { promote democracy and development. } \\
\text { Anheier, Helmut. Study of Global } \\
\text { Governance and the Centre for Civil } \\
\text { Society at the LSE (with the Center for } \\
\text { Civil Society at UCLA) p. } 17 \text {. }\end{array}$ \\
\hline GCSI & $\begin{array}{l}\text { Johns Hopkins } \\
\text { Global Civil } \\
\text { Society Index }\end{array}$ & 2004 & 0 & 100 & $\begin{array}{l}\text { Scores countries for the capacity, } \\
\text { sustainability and impact of their civil } \\
\text { society (nonprofit) sectors. Lester } \\
\text { Salamon and Wojciech Sokolowski. At } \\
\text { John Hopkins University }\end{array}$ \\
\hline Gl & $\begin{array}{l}\text { Globalization } \\
\text { Index }\end{array}$ & 2001 & $\begin{array}{l}62 \text { (lowest } \\
\text { ranked) }\end{array}$ & $\begin{array}{l}1 \text { (highest } \\
\text { ranked) }\end{array}$ & $\begin{array}{l}\text { Composite levels of international } \\
\text { integration: } 1 \text { ) trade, payments and } \\
\text { receipts, flows of FDI \& portfolio flow, } \\
\text { convergence of domestic \& world } \\
\text { prices; 2) personal contact: travel, } \\
\text { tourism, telephones; and 3) } \\
\text { technology. A.T. Kearney, Foreign } \\
\text { Policy Magazine and Global Business } \\
\text { Policy Council. }\end{array}$ \\
\hline IEF & $\begin{array}{l}\text { Index of } \\
\text { Economic } \\
\text { Freedom }\end{array}$ & 1995 & $\begin{array}{l}5 \text { (most } \\
\text { economically } \\
\text { repressed) }\end{array}$ & 1 (freest) & $\begin{array}{l}10 \text { categories measured-trade policy, } \\
\text { fiscal burden of government, } \\
\text { government intervention in the } \\
\text { economy, monetary policy, capital } \\
\text { flows and foreign investment, banking } \\
\text { and finance, wages and prices, } \\
\text { property rights, regulation and } \\
\text { informal (or black) market } \\
\text { activity-tend. Wall Street Journal and } \\
\text { The Heritage Foundation. 155-161 } \\
\text { countries }\end{array}$ \\
\hline
\end{tabular}

Appendix A - Selection of Indices (Continued)

Founded Unfavorable Good Score Source/ Brief Description

[or Year 1] Score

Ol Opacity Index $\quad 1 / 2001 \quad 150 \quad 0 \quad$ The five-dimension scale is based on (completely (completely extensive interviews with global elites opaque) transparent) such as CFOs, bankers, equity

analysts, and their own in-country consultants. PricewaterhouseCoopers.

Opacity Risk 2001

Premium

Tax Equivalent $\quad 200$
Based on the 0l. Indicates the increased cost of borrowing faced by national governments due to their own opacity $(100$ basic points $=$ one percent point increase in interest). PricewaterhouseCoopers (PwC)

Based on the 0l. Opacity will raise the cost of doing business, an estimated amount called 'Tax Equivalent'- the equivalent of a surtax on investment. PricewaterhouseCoopers. 